\title{
Threatened mammals of the Cordillera de Colán, Peru
}

\author{
Stuart H.M. Butchart, Roger Barnes, Charles W.N. Davies, \\ Mirko Fernandez and Nathalie Seddon
}

\begin{abstract}
During recent surveys in the Cordillera de Colán, a semi-isolated mountain range in northern Peru, observations were made and information collected on three species of mammals considered globally threatened with extinction-yellow-tailed woolly monkey Lagothrix flavicauda, Andean night monkey Aotus miconax and spectacled bear Tremarctos ornatus. The yellow-tailed woolly monkey has an extremely restricted range, in which extensive deforestation is occurring, and the species is also heavily hunted. The urgent establishment of an effectively protected area in the Cordillera de Colán is strongly recommended in order to help secure the future for this poorly known primate and other mammal and bird species of conservation importance.
\end{abstract}

The Cordillera de Colán is a mountain range located in Amazonas Department, northern Peru. It is surrounded by lowlands except in the south-east where it adjoins the Cordillera Central (Figure 1).

In July-August 1994 the authors carried out surveys during an expedition organized from the University of Cambridge, UK and the Asociación Peruana para la Conservación de la Naturaleza (APECO). The conservation status and habitat requirements of the threatened and endemic birds and mammals in remaining areas of cloud forest and elfin forest was assessed and surveys were carried out in these habitats at altitudes of $1500-2650 \mathrm{~m}$ at two sites in the southern part of the mountain range (Figure 1 ).

Opportunistic observations of mammals were made when they were encountered while birdwatching on and off trails in the forest, during 751 diurnal field-hours and 56 nocturnal field-hours. When primates were located visually or aurally, they were watched for as long as possible, recording group composition and behaviour. During informal conversations with local people the abundance, altitudinal preferences, and hunting of mammal species in the Cordillera de Colán were discussed. Among the species recorded were three species of mammal listed as threatened by Groombridge (1993): yellow-tailed woolly monkey Lagothrix flavicauda, Andean night monkey Aotus miconax and spectacled bear Tremarctos ornatus.

\section{Yellow-tailed woolly monkey}

Following its discovery in 1802 , the yellowtailed woolly monkey was collected again in 1925 and 1926, but then was presumed to have become extinct. It was rediscovered in 1974 (Mittermeier et al., 1975, 1977), and seen again in 1976 (Graves and O'Neill, 1980) and 1979 (Parker and Barkley, 1981). The first detailed review of the distribution and status of the species (Leo Luna, 1980) concluded that it is found exclusively in humid and very humid montane forest above $1800 \mathrm{~m}$, and that it is known to occur only at a few sites in the departments of Amazonas, San Martín and Loreto in northern Peru. Groombridge (1993) listed this species as Endangered.

Between 18 July and 5 August 1994 the authors observed the yellow-tailed woolly monkey frequently at site 1 (above Comboca at $5^{\circ} 48^{\prime} \mathrm{S} 78^{\circ} 1^{\prime} \mathrm{W}$ ) at $2220-2650 \mathrm{~m}$, most often at 2250-2350 m (Figure 1). The monkeys were 


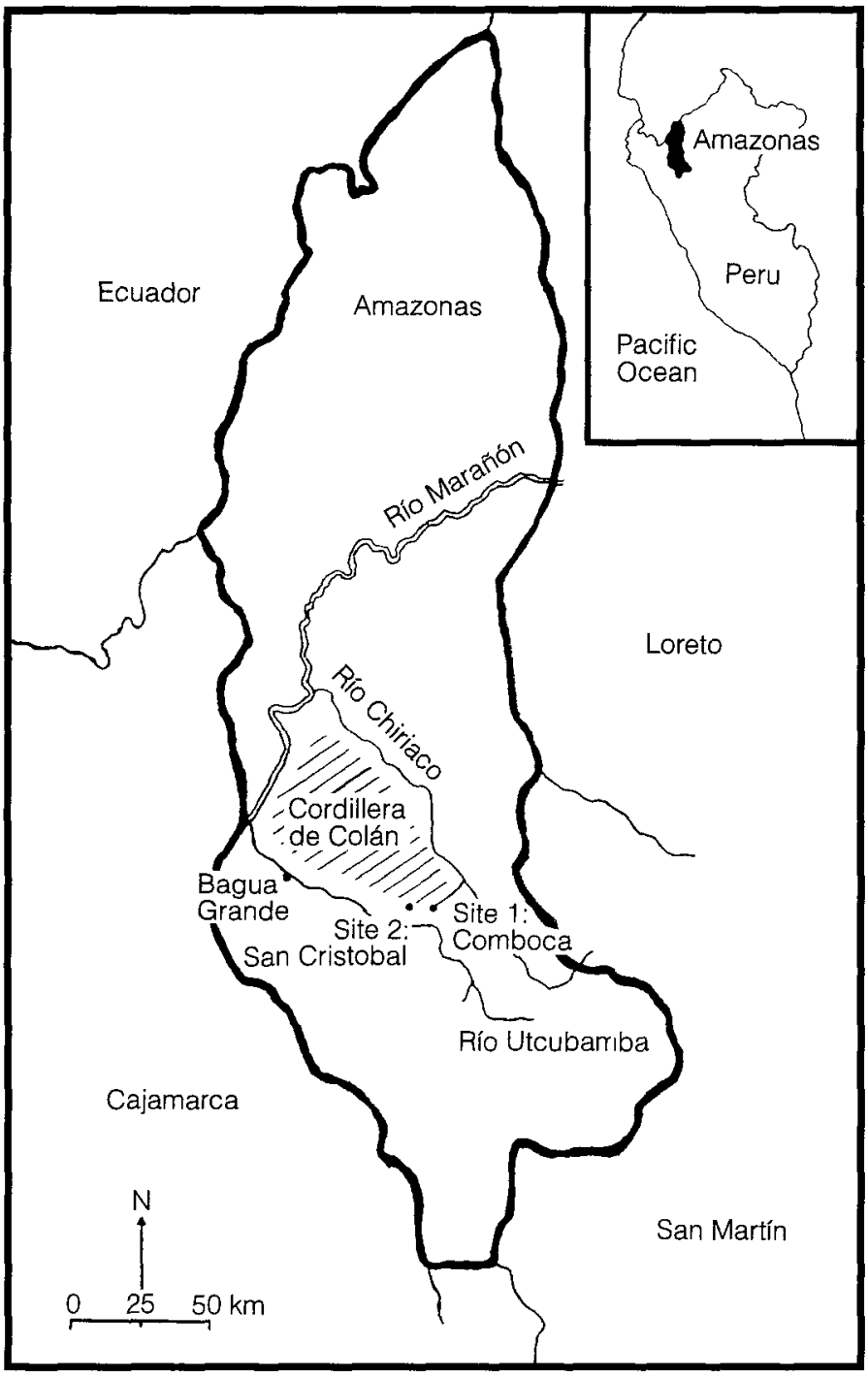

Figure 1. Map showing study sites in the Cordillera de Colán.

found in very humid lower montane cloud forest (Holdridge et al., 1971) at altitudes where there was little human disturbance. The forest was frequently enshrouded in mist and was characterized by a canopy height of $20-25 \mathrm{~m}$, a dense midstorey and understorey, abundant moss and epiphytes, and many tree ferns.

Thirteen sightings were made. Most of these were probably of the same group of monkeys, but two records on 27 July at widely separated altitudes suggest that perhaps two groups were involved. Two groups seen on 20 and 31 July both contained at least three adult males, and numbered at least 10 individuals. Leo Luna (1980) also recorded a maximum group size of 10, but Hendee reported a troop of 20 individuals in 1926 (Thomas, 1927; Mittermeier et al., 1977). In contrast, the Humboldt's, or common, woolly monkey Lagothrix lagotricha has been recorded in groups of up to 70 individuals, with mean group sizes ranging from 5.5 to 40 individuals in different studies (Wolfheim, 1983). Large groups of yellowtailed woolly monkeys must be very rare now, given the hunting pressures on this species. Other observations on the ecology of the 
Cloud forest in the Cordillera de Colán from $1900 \mathrm{~m}$ at site 1

(Stuart Butchart).

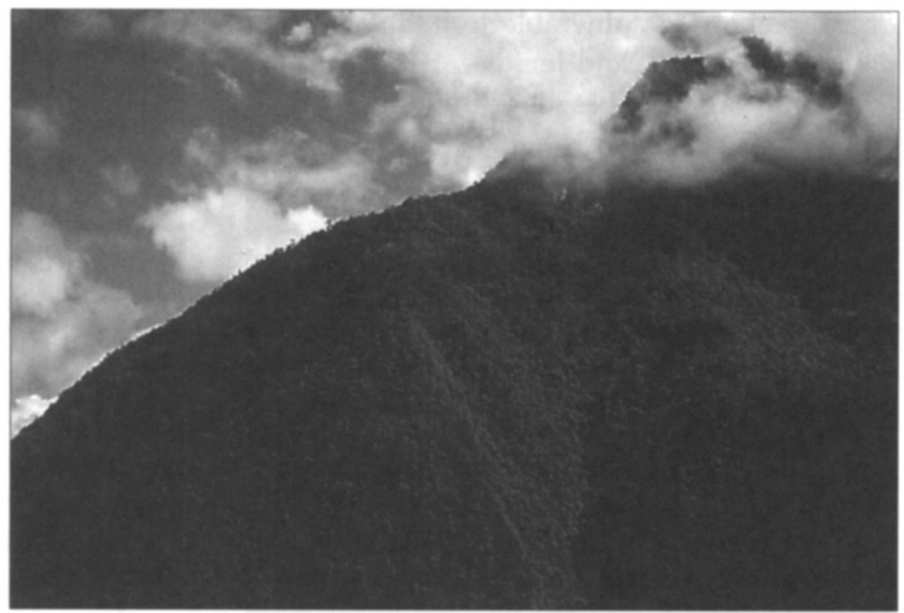

yellow-tailed woolly monkey will be presented elsewhere (Butchart et al., in press).

The species was reported by local people to be uncommon between 2000 and $2650 \mathrm{~m}$ in very humid lower montane forest at site 1 . The authors did not record this species at site 2 (above San Cristobal at $5^{\circ} 48^{\prime} \mathrm{S} 78^{\circ} 6^{\prime} \mathrm{W}$ ), probably because of the lower altitude (of the forest), and the higher levels of human disturbance. It was reported to have become extinct through hunting at this site.

The Humboldt's woolly monkey Lagothrix lagotricha is highly endangered as a result of persecution by hunting for food and for obtaining infants for pets. The species's large body mass, tameness, clustered distribution, and relatively low reproductive output render it highly susceptible to hunting (Foden, 1963; Wolfheim, 1983; Peres, 1991), and it has been driven to local extinction in most areas where it is hunted (Peres, 1991). The yellow-tailed woolly monkey is likely to be similarly susceptible to hunting. Mittermeier et al. (1977) noted that the species was attractive to hunters, being large, conspicuous and confiding, and Leo Luna (1980) concluded from the composition of groups she observed that the species has a low birth rate. Thornback and Jenkins (1982) noted that this species was often the first primate to disappear following human encroachment into suitable habitat. At least two individuals at site 1 had been shot for food in May-June 1994. In addition, the species seems unable to adapt to secondary
Spectacled bear shot by a local hunter in the Cordillera de Colán (Roger Barnes).

(C) $1995 \mathrm{FFI}$, Oryx, 29 (4), 275-281

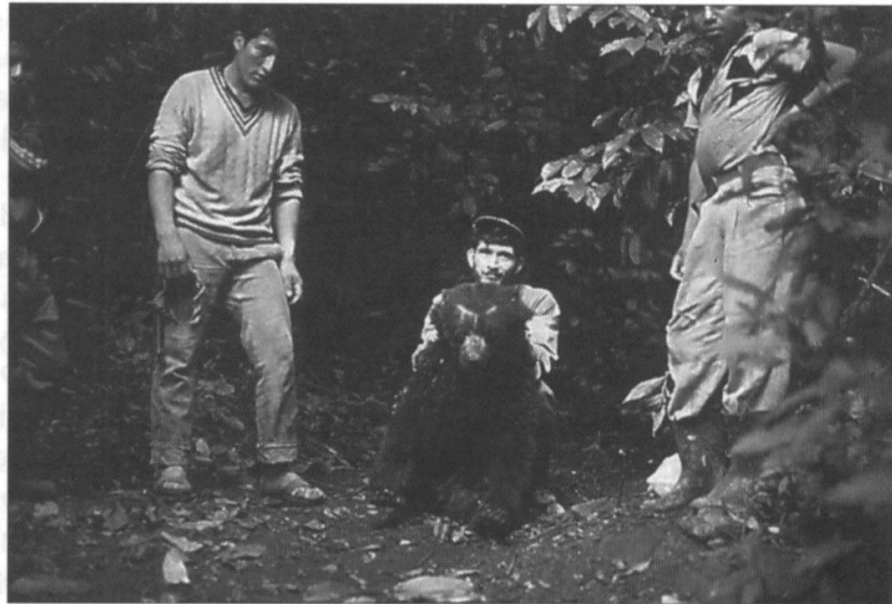

277 
forest, making it vulnerable to habitat degradation (Thornback and Jenkins, 1982). Threats from hunting, combined with a highly restricted range in which habitat destruction is occurring at a rapid rate, render the yellowtailed woolly monkey critically endangered.

All previous reports of the species, including the 1980 study, emphasized that the yellow-tailed woolly monkey is highly threatened and recommend the establishment of a forest reserve. Since these recommendations were made, large-scale deforestation has occurred (Davies et al., 1994). The species has been found in Río Abiseo National Park to the south (Leo Luna, 1993), but a further protected area is necessary for effective conservation of this monkey. Such a reserve in the Cordillera de Colán would also protect a number of other species of conservation importance.

\section{Andean night monkey}

Night monkeys Aotus spp. are generally fairly common, but the Andean night monkey A. miconax is of conservation importance and is listed as Vulnerable in Groombridge (1993) because of its restricted range in the eastern Andes of Peru, south and east of the Río Marañón and west of the Río Huallaga (Hershkovitch, 1983). Hershkovitch (1983) assigned miconax specific status on the basis of differences in pelage, mainly the extent of orange on the underparts. The most recent review of the distribution and taxonomy of night monkeys (Ford, 1994) found miconax to be distinct only in cranial dimensions and concluded that its taxonomic status is still unclear. The karyotype, on which most recent taxonomic revisions in the genus have been based, has yet to be determined (Hershkovitch, 1983; Ford, 1994).

The authors recorded night monkeys between 15 July and 17 August at both sites visited in the Cordillera de Colán, an area where Hershkovitch (1993) and Ford (1994) indicated that A. miconax is the only form found. They were observed from 1730 to $2300 \mathrm{~m}$ in humid and very humid lower montane cloud forest in areas with fairly low levels of human dis- turbance. From 15 to 21 July observations were made on consecutive nights of the same group of two to three night monkeys feeding in the canopy of a fruiting fig tree at $1860 \mathrm{~m}$ at site 1.

Night monkeys were locally reported to be common in the area of the study sites, and a group was reported to be seen regularly in a clump of fruiting trees at $1100 \mathrm{~m}$ in Comboca village. In addition, an individual kept as a pet was seen in San Cristobal village, at $700 \mathrm{~m}$, and it was presumed that it had been captured locally. However, local people apparently do not hunt this species for food. Aquino and Encarnación (1988) also reported that night monkeys (A. nancymai and A. vociferans) in Peruvian lowland Amazonia were not hunted and ascribed this to their small size and nocturnal habits.

The Andean night monkey appeared to be fairly common in the Cordillera de Colán and is probably found between 1200 and $2300 \mathrm{~m}$. It is threatened primarily by deforestation and, while it may occur in the Riò Abiseo National Park to the south (Aquino and Encarnación, 1994), an officially designated area to protect the yellow-tailed woolly monkey in the Cordillera de Colán would also protect habitat supporting the Andean night monkey.

\section{Spectacled bear}

The spectacled bear was observed only once during the survey. An individual was seen briefly at $05.45 \mathrm{~h}$ on 28 July in humid lower montane cloud forest at $2300 \mathrm{~m}$ at site 1 . The species is locally reported to be fairly common at $1000-2650 \mathrm{~m}$. It is hunted intensively for food because of its large size and good meat. It is also considered to be a pest because it raids crop fields and attacks livestock, behaviour that has been previously noted for this species in Peru (Peyton, 1980) and elsewhere (e.g. Goldstein, 1991). On 15 July the authors were shown a freshly shot individual that had been taken by local hunters in humid lower montane cloud forest above $1550 \mathrm{~m}$ at site 1 . Signs of bears were found in very humid lower montane ridge-top cloud forest at $2600-2650 \mathrm{~m}$ at 


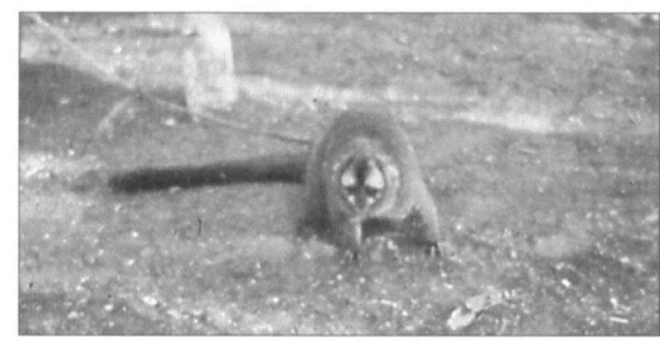

A captive Andean night monkey Aotus miconax, San Cristobal, Cordillera de Colán (Stuart Butchart).

site 1, including scats, a tree-trunk heavily scratched up to a height of $2 \mathrm{~m}$, and a wellworn path, which local hunters said had been made by a bear, running along a fairly flat narrow ridge-top. Peyton (1981) also noted bear trails rumning along ridge-tops. A study of this species in Peru in the late 1970s (Peyton, 1980) concluded that the best habitat for bears was humid forest between 1900 and $2350 \mathrm{~m}$. Similarly, in Venezuela Goldstein (1990) found that the key habitat for spectacled bears occurred at humid sites between 2000 and $2500 \mathrm{~m}$. Such habitat is being rapidly degraded, and a protected area containing suitable habitat in the Cordillera de Colán would support the conservation of this species in Peru.

\section{Other species}

Eight other species of medium-large mammals were recorded in the Cordillera de Colán: brown capuchin Cebus apella, South American coati Nasua nasua, striped hog-nosed skunk Conepatus semistriatus, tayra Eira barbara, longtailed weasel Mustella frenata, puma Felis concolor, porcupine Coendou sp. and black agouti Dasyprocta fuliginosa.

A further 14 mammal species were reported by local people, but were not observed by the authors: giant anteater Myrmecophaga tridactyla, southern tamandua Tamandua tetradactyla, brown-throated three-toed sloth Bradypus variegatus, white-fronted capuchin Cebus albifrons (also kept as a pet in San Cristobal village), red howler monkey Alouatta seniculus, whitebellied spider monkey Ateles belzebuth,

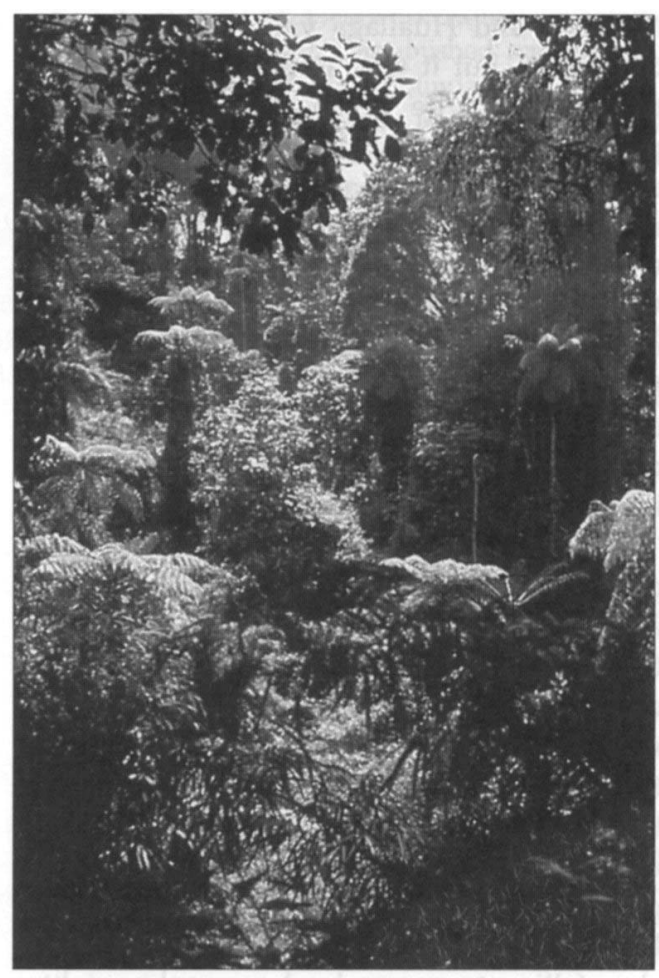

Cloud forest at $2300 \mathrm{~m}$ at site 1 in the Cordillera de Colán (Nathalie Seddon).

southern river otter Lutra longicaudis, ocelot Felis pardalis, Brazilian tapir Tapirus terrestris, collared peccary Tayassa tajacu, grey brocket deer Mazama gouazoubira, white-tailed deer Odocoileus virginianus, paca Agouti paca and pacarana Dinomys branickii.

A total of 328 bird species was recorded (Davies et al., 1994), including five species considered threatened with extinction (Collar et al., 1994). One of these, the military macaw Ara militaris, would be highly suitable for use as a conservation flagship species, being large, colourful and well-known to the local people.

\section{Conservation of the Cordillera de Colán}

In 1978 it was reported that large areas of forest in the Cordillera de Colán remained intact (T. S. Schulenberg in Collar et al., 1992). Before the authors' visit in 1994 it was known that nearby population centres such as the 
Marañón and Huallaga valleys were heavily deforested, but it was assumed that forest in the Cordillera de Colán was still relatively pristine. This was despite warnings that midelevation areas were increasingly being deforested for agriculture (Leo Luna et al., 1988). It was also known that the range is particularly vulnerable to human activities because an unusually cool local climate with frequent rainfall results in stunted ridge-top forest extending down to about $2000 \mathrm{~m}$, considerably lower and therefore more accessible, than in most other areas (Collar et al., 1992).

In 1994 the authors observed large-scale deforestation in the Cordillera de Colán, and areas in the north of the range were reported to be completely degraded. Significant areas of forest remain only in the south-east of the range. Even here it is being degraded by selective logging using chainsaws for Cedrella timber, and being cleared rapidly by local people using axes and fire to produce land for cattle grazing and subsistence agriculture. The problems are also exacerbated by the custom of clear-felling to secure land ownership rights; large areas have been cleared without subsequent use for agriculture. Mule trails for removing timber have increased access to the forest, facilitating hunting and further habitat degradation. It is vital that conservation action is initiated rapidly because local people estimate that, at the current rate of deforestation, all forest will be degraded within 10 years. Furthermore, two of the species discussed here, yellow-tailed woolly monkey and spectacled bear, are particularly threatened by hunting. As human pressures on the remaining forest increase, these are the species that will be driven to local extinction first.

The presence of three threatened mammals and a number of other mammal and bird species of conservation importance in an area with such rapid rates of deforestation leads us to conclude that the conservation situation in the Cordillera de Colán is critical. We strongly recommend that an effectively protected area should be established urgently in the southern part of the range. It is here that the largest area of intact forest supporting populations of important mammals and birds remains. The local security situation has recently improved and the area is not influenced by the border dispute with Ecuador. A conservation scheme should take advantage of this as well as the local interest and desire to help conserve the remaining forest (Davies et al., 1994). The local mayor has recommended that, as well as protecting intact forest, local pressures on the forest need to be reduced by a programme of reforestation to provide timber and by pasture improvement at lower altitudes to reduce the need for hunting. A protected area is feasible, but if it is not established soon major losses will occur in the biodiversity of this region.

\section{Acknowledgements}

All advisors and sponsors of the expedition during which this field-work was carried out are fully acknowledged in our report (Davies et al., 1994), available from Charles Davies at the address below. We would also particularly like to thank: the late Gerald Durrell, our patron; Rob Clay, for advice and support; staff at the Asociación Peruana para la Conservación de la Naturaleza (APECO), particularly Dr Mariella Leo Luna, for valuable assistance and advice; and staff at BirdLife International, Cambridge, particularly Adrian Long, Michael Poulson, Beatrice Torres and Dave Wege. Joe Tobias and two anonymous referees provided helpful comments on a draft of this manuscript. Above all, we wish to thank Daniel La Torré Lopez, our indefatigable and knowledgeable local guide.

\section{References}

Aquino, R. and Encarnación, F. 1988. Population densities and geographic distribution of night monkeys (Aotus nancymai and Aotus vociferans) (Cebidae: Primates) in Northeastern Peru. Am. J. Primatol. 14, 375-381.

Aquino R. and Encarnación, F. 1994. Owl monkey populations in Latin America: field work and conservation. In Aotus: The Owl Monkey (eds J. F. Baer, R. E. Weller and I. Kakoma), pp. 59-95. Academic Press, San Diego.

Butchart, S.H.M., Davies, C.W.N., Barnes, R., Fernandez, M. and Seddon, N. In press. Recent observations of two threatened primates in the Peruvian Andes. Primate Conservation.

Collar, N.J., Gonzaga, L.P., Krabbe, N., MadroñoNieto, A., Naranjo, L.G., Parker, T.A. and Wege. D.C. 1992. Threatened Birds of the Americas: The ICBP/IUCN Red Data Book. International Council 
for Bird Preservation, Cambridge, UK.

Collar, N.J., Crosby, M.J. and Stattersfield, A.J. 1994. Birds to Watch 2: The World List of Threatened Species. BirdLife International, Cambridge, UK.

Davies, C.W.N., Barnes, R., Butchart, S.H.M., Fernandez, M. and Seddon, N. 1994. The Conservation Status of the Cordillera de Colán. Unpublished report.

Foden, J. 1963. A revision of the woolly monkeys (genus Lagothrix). J. Mamm. 44, 213-247.

Ford, S.M. 1994. Taxonomy and distribution of the owl monkey. In Aotus: The Owl Monkey (eds J. F. Baer, R. E. Weller and I. Kakoma), pp. 1-57. Academic Press, San Diego.

Goldstein, I. 1990. Distribución y habitos alimentarios del oso frontino, Tremarctos ornatus, en Venezuela. MSc thesis, Universidad Simón Bolivar, Venezuela.

Goldstein, I. 1991. Spectacled bear predation and feeding behaviour on livestock in Venezuela. Studies on Neotropical Fauna and Environment, 26 (4), 231-235.

Graves, G.R. and O'Neill, J.P. 1980. Notes on the yellow-tailed woolly monkey (Lagothrix flavicauda) of Peru. J. Mamm. 61 (2), 345-347.

Groombridge, B. (ed.) 1993. The 1994 IUCN Red List of Threatened Animals. International Union for Conservation of Nature and Natural Resources, Gland, Switzerland and Cambridge, UK.

Hershkovitch, P. 1983. Two new species of night monkeys. genus Aotus (Cebidae, Platyrrhini): a preliminary report on Aotus taxonomy. Am. J. Primatol. 4, 209-243.

Holdridge, L.R., Grenke, W.C., Hatheway, W.H., Linag, T. and Tesi, J.A. 1971. Forest Environments in Tropical Life Zones: A Pilot Study. Wiley and Son, New York.

Leo Luna, M. 1980. First field study of the yellowtailed woolly monkey. Oryx, 15, 386-389.

Leo Luna, M. 1993. The importance of tropical montane cloud forest for preserving vertebrate endemism in Peru: the Río Abiseo National Park as a case study. In Tropical Montane Cloud Forests: Proceedings of an International Symposium (eds L. S. Hamilton, J. O. Juvik and F. N. Scatera), pp. 126-133. Association for Tropical Biology, University of Puerto Rico.

Leo Luna, M., Ortiz, E. and Rodriguez, L. 1988.
Results of the 1988 Fieldwork Faunal Inventory: Río Abiseo NP, Peru. Unpublished report to the David and Lucille Packard Foundation.

Mittermeier, R.A., Macedo Ruiz, H. de and Luscombe, A. 1975. A woolly monkey rediscovered in Peru. Oryx, 13, 41-46.

Mittermeier, R.A., Macedo Ruiz, H. de, Luscombe, B.A. and Cassidy, J. 1977. Rediscovery and conservation of the Peruvian yellow-tailed woolly monkey (Lagothrix flavicauda). In Primate Conservation (eds Prince Rainier of Monaco and G. H. Bourne), pp. 95-115. Academic Press, New York.

Parker, T.A. and Barkley, L.J. 1981. New locality for the yellow-tailed woolly monkey. Ory $x, 16,71-72$.

Peres, C.A. 1991. Humboldt's woolly monkeys decimated by hunting in Amazonia. Oryx, 25, 89-95.

Peyton, B. 1980. Ecology, distribution and food habits of spectacled bears, Tremarctos ornatus, in Peru. J. Mamm. 61 (4), 639-652.

Peyton, B. 1981. Spectacled bears in Peru. Oryx, 16, 48-56.

Thomas, O. 1927. A remarkable new monkey from Peru. Ann. Mag. Natur. Hist. 19 (9), 156-157.

Thornback, J. and Jenkins, M. 1982. The IUCN Mammal Red Data Book. Part 1: Threatened Mammalian Taxa of the Americas and the Australasian Zoogeographic Region. IUCN, Gland, Switzerland.

Wolfheim, J.H. 1983. Primates of the World: Distribution, Abundance and Conservation. Harwood, Chur, Switzerland.

Stuart H. M. Butchart, Department of Zoology, Downing Street, Cambridge CB2 3EJ, UK.

Roger Barnes, 4 Claremont Drive, Leeds LS6 4ED, UK.

Charles W. N. Davies, Clare College, Cambridge CB2 1TL, UK.

Mirko Fernandez, c/o APECO, Parque José de Acosta 187, Magdalena del Mar, Lima 17, Peru.

Nathalie Seddon, Newnham College, Cambridge CB3 9DF, UK. 